\title{
An Ethnographic Textual Analysis of Aging ANd the Elders in South WESTERN Nigeria
}

\author{
Ayokunle Olumuyiwa Omobowale
}

\begin{abstract}
Among the Yoruba of South-Western Nigeria aging represents a valued process leading to a stage in life when an individual assumes the position of an elder and is accorded reverence and awe. The aged, who are attributed to be elders, are highly valued because of the belief that they are the repository of experience, knowledge and wisdom that are germane to societal survival. Despite the respect accorded them, elders are also, in turn, expected to exhibit noble character as the contextual local culture demands. These expectations are reflected in indigenous social thought and Atari Ajanaku's Agbalagba and Agba Langba poems. This study analyzed these poems using Akiwowo's Theory of Sociation. The theory contextually explains the Yoruba social organization and social behaviour noting the concepts of iwa (character), ihuwasi (behavioural pattern), isesi (pattern of doing or simply action) and ajumose (doing in unison) as integral characteristics of the local social structure without which, the local social structure may not be contextually understood. The data for the study were generated from Atari Ajanaku's poems on the elder and subjected to ethnographic analysis.
\end{abstract}

Keywords: Aging; Ethnography; Textual Analysis; Nigeria; Yoruba

Résumé. Chez les Yoruba du sud-ouest du Nigéria, le vieillissement représente un processus estimé conduisant à un stade de la vie où une personne prend la position d'un aîné et est accordée respect et vénération. Les personnes âgées qui sont attribués à être des aînés sont hautement considérés à cause de la croyance qu'ils sont les dépositaires de l'expérience, les connaissances, et la sagesse qui sont germane à la survie de la société. Malgré tout le respect qui leur est accordée, les aînés devront présenter un caractère noble que la culture locale exige. Ces attentes se reflètent dans la pensée sociale indigène et dans les poèmes d'Atari Ajanaku Agbalagba et Agba Langba. Cette étude a analysé ces poèmes en utilisant la théorie de Akiwowo, qui s'appelle la Théorie de Sociation. La théorie explique contextuellement l'organisation sociale de Yoruba et le comportement social, prenant note des concepts de iwa (caractère), ihuwasi (schéma de 
comportement), Isesi (motif de le faire ou tout simplement l'action) et ajumose (faire à l'unisson), comme des caractéristiques intégrante de la structure sociale locale, sans laquelle la structure sociale locale ne pourrait pas être contextuellement compris. Les données de l'étude ont été générés à partir des poèmes de Atari Ajanaku sur l'aîné. Les données générées ont été soumis à une analyse ethnographique.

Mots-clés: Vieillissement; ethnographie; analyse de texte; Nigeria; Yoruba

\section{INTRODUCTION}

1] ging constitutes strategic reference points across societies. The conStext and content of the reference points differ from one society to the other. In most Third World nations imbued with traditional values, the aged are regarded as elegant and respected members of the society whose depth of experience, knowledge and wisdom could enhance societal survival and development (Shijun 1993; Johnson and Climo 2000; Baldridge 2001). This contrasts with the notion of the aged as a potentially weak and endangered group deserving apposite social intervention, protection and care in much of the industrialized world (Coupland 2007; Smyer and Clark 2011; Richardson and Zorn 2012; Sigurdardottir, Sundstrom, Malmberg and Bravell 2012). Irrespective of the contrasting social approaches in "visualizing" aging, it is pertinent to note that the aged constitute a unique social group across cultures. They represent a social group who have experienced the vibrancy of youthful life, gone through the middle-age, gradually proceeded to old age at retirement and are advancing in the "aged" years; gradually or rapidly moving through frailty unto eventual death.

Among the Yoruba of South-Western Nigeria, aging presents a social phenomenon culturally defined in glowing terms. The Yoruba perceive aging as a gradual process of ascent into the realm of ancestorship. This is predicated in the Yoruba belief in "life-after-death", where dead members who lived up to ripe old ages, at death, are assumed to have translated into the "supernatural" to protect the living members of the community (Adediran 1985, Alana 2004). The pains and frailty associated with aging, are redefined in socially "valued" conceptions, obliterating the negativity of aging, and thus re-creating the aging and/or the aged as the repository of experience, knowledge and wisdom that is vital for societal survival. Hence, Yoruba social thought describes the grey hair as the "crown" of the aged. The "crown" as stated here represents the epitome of social appreciation accorded the aged among the Yoruba. It is noteworthy to state however, that an individual assumes the social honour that accompanies the aged provided he or she internalizes and 
exhibits socially approved norms and values in the expression of his or her character. This is exclusively presented in Yoruba social thought and in Atari Ajanaku's ${ }^{1}$ poems that distinguish between the noble and the ignoble elder (see Atari Ajanaku 1998). An examination of social thought, fictional texts and poems in the understanding of social structure, social relations and everyday life is a recent social method that is progressively gaining ground (see Olutayo 2012, Omobowale 2008a, Hepworth 2003, 2000 for examples)

The life and social experiences of aging and the aged have been variously captured in literature (and fiction). Blaikie (1999) captures the progression and changes in life experiences and social expectation and perception of the aged in his book Aging and Popular Culture. Blaikie identified the Third Age (immediate post-retirement period) and the Fourth Age (advanced old age) as gerontological stages. Due to improved medical and welfare care especially in the Western world, more people are living to ripe old ages. This has resulted in a large population of aged who present unique lifestyles and challenges even in frailty. Blaikie's research shows the modernity/consumerism influenced changing lifestyle of British aging population who age "positively". He presents modern positive aging lifestyles of vitality, agility and leisure through an analysis of pictures, cartoons and magazines images. In short, through analysis of symbolic fictional imagery of aging in the modern world, Blaikie shows positive aging as contemporary lifestyle of the elderly that is influenced by popular culture. Blaikie's research is confirmed by empirical research on alcoholism (McCabe 2011), consumerism (Coupland 2007) and sexual virility of the elderly (Marshall 2006; Marshall and Katz 2002).

Among Western scholars, researching the context of old age through analyses of fiction and poetry has emerged through a vibrant scholarly engagement. For example Hepworth (2000) in Stories of Aging utilizes symbolic interactionism to analyze fictional novels and thus discusses the aging body and self, material/consumer preference and the vulnerability of the aged. In another work, Hepworth (2003) examines the social experience of aging in the fictional works of novelist Stanley Middleton. Clark (1980), Hagley (1988) and Moran (2001) discuss the presentation of the elderly as exposed, alienated and frail in poems and fictional narratives. On the other hand Boland (1994) and Jamieson (2004) examined

1. Atari Ajanaku is the pen-name of Professor Adedotun Ogundeji. Adedotun Ogundeji is a Professor of Linguistics and African Languages in the University of Ibadan. A distinguished scholar, vast in Yoruba oral literature and philosophy, Ogundeji was Dean of Ibadan University Faculty of Arts from 2009 to 2011. Agbalagba and Agba Langba poems are part of Orin Ewuro (Songs of the Bitter-Leaf); an anthology of 30 Yoruba poems by Atari Ajanaku. 
positive aging in fictional novels and poems. Simply put, aging fictions and poems are writers' reflections of social perceptions and contexts of gerontology. Hence, contextual analyses of fictional texts and poems on the aged potentially reveal the sociology of the aged in a society. Whereas western scholars have produced numerous scholarly treatises on textual analysis of gerontology in fiction and literature, it is difficult to access such mass in African/Nigerian literature. Hence, the principal focus of this paper is an ethnographic textual analysis of the aged among the Yoruba of South-Western Nigeria. Among the Yoruba, the aged are highly regarded and revered. As custodians of the societal culture and heritage, the aged are considered the epitome of wisdom, experience, knowledge and noble character deserving the awe and emulation of the younger generation. Nevertheless, the indigenous social structure derides the aged who fails the subsisting normative value. Atari Ajanaku captures the high honour and social bewilderment that accompanies the noble elder and the ignoble elder in his Agbalagba and Agba Langba poems respectively. This paper utilizes the Asuwada Theory of sociation to analyze the Agbalagba and Agba Langba poems.

This paper sociologically examines Yoruba normative value on the Elder's character. The paper builds on this premise by complementing the analysis of the Agbalagba and Agba Langba poems with an examination of relevant aspects of Yoruba social thought on the aged. The $A g$ balagba and Agba Langba poems have been specially selected because of their deep reflections on socio-normative values which the Yoruba cultural milieu demands the aged should eschew (Agbalagba) and the social bewilderment and stigmatizing disdain that accompany an aged's social misnomer (Agba Langba). This study relies on the Akiwowo's theory of sociation as theoretical guide. The theory was adopted as the theoretical guide because of its postulation on the indigenous social relations and context. It is therefore, capable of providing apposite guide that could engender the right contextual explanation on the "aged's character".

Against the principal focus of this paper on the aged and character, literature generally discusses the social world and experience of the aged with regards to health and care (Christoffersen 1974, Johnson and Climo 2000, Krekula 2007), abuse, maltreatment and vulnerability (Bužgová 2009; Hodell et al 2009; Post et al 2010; Brozowski and Hall 2010, Amstadter et al 2011, Begle et al 2011), active aging (Ranzijn 2010) and the conceptions of aging in the developed and developing worlds (Shijun 1993, Zhan and Montgomery 2003). This paper is aimed at filling the lacuna that neglects the social conception of the aged in relation with their (the aged's) character. This is because, the social perception of the 
character of the aged, potentially impacts social behavior and response to the aged, especially among the Yoruba of South-Western Nigeria.

Once again, this paper notes that Yoruba poetry (along with other elements of the indigenous social thought) is a major means of contextually understanding Yoruba normative values. ${ }^{2}$ Hence, this paper examines Yoruba normative values on the aged's character by exploring the relevant aspect of Yoruba social thought and examining Atari Ajanaku's ${ }^{3}$ Agbalagba and Agba Langba poems using Akiwowo's theory of sociation as theoretical guide.

\section{Methodology}

The data for the study were sourced from relevant aspects of Yoruba social thought ${ }^{4}$ on the aged and Atari Ajanaku's Agbalagba and Agba Langba poems. The Yoruba are predominantly located in South-Western Nigeria. Other Yoruba groups are also located in Benin Republic and Togo. Though separated by colonial geographical boundaries and language $^{5}$, the Yoruba groups across the three countries share the same native language and culture. In spite of modernity influenced by colonization and post-colonization dominance of Westernization, the Yoruba take indigenous culture as integral to everyday life. Even in instances where elements of the modern culture are noticeable, the native culture remains resilient. This is evident in greeting forms, salutations, belief systems, traditional political institutions and social conceptions about the elderly, among other issues.

\section{Character-in-Sociation and the Aged}

This study adopted Akiwowo's theory of sociation as a theoretical guide to contextually explain the social relations of the expected aged char-

2. See Daniel et al 1987, Ihinger-Tallman 1987, Ganetz 1994, Cummings 2002, Conrad 2012, Nyamnjoh 2012 for some contextual analysis of poetry.

3. Atari Ajanaku's poems represent contemporary critical indigenous thoughts on normative values. These poems further accentuate the standards of indigenous normative values that have been embedded in Yoruba social structure since time immemorial.

4. Yoruba social thought present veritable data source for the understanding of Yoruba social life, culture and social structure (see Olatunji 1970, 1979, 1984, Olajubu 1972, Omowoleya 1972, Ojoade 1983, Richards 1984, Ogundeji 1991, Agbaje 2002, Akinyemi 2003, Salawu 2011, Akanle and Olutayo 2011, 2012).

5. The Yoruba in Nigeria are Anglophone while those in Benin Republic and Togo are Francophone. 
acter in everyday life. In particular, Akiwowo's theory emphasizes the place of character and its consequent expression through action for societal good/unity, in the sustenance of the social structure. Hence, the normative expression of character as defined by the immediate social environment impacts the social perception and acceptance of the interacting individual. In the case of the aged, the character the aged eschews, impacts the social honour and awe that he/she may attract.

Professor Akiwowo propounded his theory of sociation in the 1980s. The theory was an epistemic opening (Adesina 2002) from the relativist circles. Sociation theory attempted to provide an indigenous theoretical postulation to explain African social structure and social relations that dominant universalist theories may be incapable of appositely defining (Omobowale 2008, Makinde1988). Akiwowo derived the theory from Yoruba poetry that was usually chanted when a new community was to be created. The chant emphasizes the importance of association in societal survival and development. Akiwowo published his postulations in his Inaugural Lecture in 1980 and in both International Sociology and Ife: Annals of the Institute of Cultural Studies in 1986 (Akinwowo $1983 ; 1986 \mathrm{a}, 1986 \mathrm{~b}$ ). The focal emphasis of the theory is sociation (association). It accounts for how constituent individuals in a society sociate and the normative values which makes sociation possible. Notably, the theory points out that in as much as the individuality of a person is recognized, the individual is socially relevant only if and when he appositely sociates for the advancement of his/her community.

Akiwowo's theory of sociation describes the "unity of social life" as the individual's life, being, existence or character. This means that social life is impossible without the constituent individuals. The contributions of individuals create a reality of the "social" in the interacting community. Without the interacting social, the existence and being of the individual is rather meaningless, because the interacting network of individuals creates and re-creates meaningful social life with embedded norms and values. Thus, the symbiotic relationship between the individual and the group (interacting social) impacts both the individual and the group in ways that define the values of individual and group existence, interactions and sustenance. Even though the community cannot be without the individual, the essence of each individual lies in the community. An individual must, therefore, sociate with other individuals in order to make a social being that would be relevant and/or functional in his/her society. Refusal to associate (sociate) or self-alienation is dysfunctional to corporate existence and is thus tantamount to deviance. In spite of this, a good society recognizes the individual's right to self-actualization and achievement of individual goals. The individual must, however, achieve 
self-actualization and/or his/her goals within the social bounds that are stipulated by the community's normative essence and values. Every individual is capable of initiating a good action (socially approved) or bad action (socially disapproved). The sociating individual therefore is one who exhibits good action and thus contributes to the achievement of societal goal and social survival. That good action is measured by an actor's exhibited character. Hence Akiwowo concludes that the conceptual values of iwa (character), ihuwasi (behavioral pattern), isesi (pattern of doing, or simply action) and ajumose (doing in unison) (see Akiwowo 1980, Omobowale 2008a) are essential in the understanding of the actions of Africans (and in this case, the Yoruba).

In essence,character stands out as a major denominator of social relationship. An interacting individual or actor is assessed, rewarded and sanctioned on the basis of his/her character as socially and normatively defined $^{6}$. The social value of an interacting individual's character is reflected in his/her behavioural pattern and action. Ultimately, the trio of character, behavioural pattern and action are germane to societal survival and progress. This is because internalized normative character, expressed in behavioural pattern and action potentially ensures unison purpose in the social structure for common or social good in everyday life.

Whereas Akiwowo's contribution has received scholarly accolades especially from Makinde (1988), Sanda 1988, Payne (1992), Adesina (2002) and Omobowale 2008, it has also attracted criticism from other scholars. For example Olutayo (2012) dismissed Akiwowo's contribution, claiming Akiwowo did not consider the contextual meanings of progress in African proverbs. Sztompka (2011) described Akiwowo's contribution as a failed attempt at providing alternative theory through his clamour for African indigenous sociology. Sctompka submits that Akiwowo only succeeded in advancing the ideas that had been acknowledged in mainstream sociology. Finally the main argument of Lawuyi and Taiwo (1990) against Akiwowo's theory is that Akiwowo did not differentiate between suwada (co-existence ${ }^{7}$ ) and suwada (co-existence for-a-purpose). This paper posits that the mere differentiation between co-existence and co-existence for-a-purpose does not in any way whatsoever detract from the validity of the theory. Besides, the ultimate context of co-existence (that is suwada) is association for social good, survival and progress. Hence, social good and survival for development is the

6. The person who has internalized the right and socially approved complement of character is described as omoluabi (good person). Among the Yoruba omoluabi is the epitome of good character and virtue (Faleti 2009, Ogundeji 2009).

7. Co-existence also contextually means association or sociation. 
purpose of sociation as defined by Akiwowo's theory. The indigenous social structure seeks to internalize the normative essence of the socially valued character, thus building a society of "good persons" exhibiting the right and wholesome complement of good character irrespective of age and social status for community good. Hence, this paper dismisses the submissions of Olutayo, Sztompka and Lawuyi and Taiwo on the contribution of Akiwowo to sociological discourse. Against the critique of Akiwowo, this paper posits that the sociation theory presents a contextual postulation for the understanding of indigenous social structure, social relations and culture especially among the Yoruba of Southwestern Nigeria.

The internalization of normative character, right from childhood through adulthood and old age, presents the aged as an individual with sufficient valuable experience, and thus noble. The normative aged is assumed to be capable of utilizing the combination of his internalized good character and social experience to enhance sociation for community unity and good. The aged serve as the custodians of community tradition, customs and culture aimed at social perpetuation of the community. The aged provide the wealth of their experiences in ensuring social stability and order in the overall aim of community advancement (Adegbindin 2011). It is also important to note that the aged are seen as good examples who have successfully internalized societal normative values. They serve as rallying points in the quest for togetherness or working in unison for community progress. Nevertheless, there are instances when some aged people may fall short of the community expectations in their character. Such aged persons would not necessarily retain their places of pride in the community social structure ${ }^{8}$. Just as a non-compliant young would be disdained and sanctioned (Omobowale 2008), the irresponsible aged loses respect and he or she is socially stripped of the prestige and honour which comes with old age. It is important to note that old age does not automatically confer prestige, respect and honour. Old age only complements the values associated with good character, provided the aged expresses the socially normative character for social unity and progress. The lack of normative character and its associated elements renders old age or the place and essentiality of an aged person rather irrelevant and incongruent. In the next two sections, the noble aged and ignoble aged are examined in context.

8. The aged who infracts the socially normative value is described as ignoble elder (agbalagba ti $n$ se langba langba). 


\section{The Noble Aged: Agbalagba}

Just as Blaikie (1999) and Hepworth (2000) examined the social world of the aged in fiction, this section and the one following ethnographically discusses the social construction of the aged's character in Yoruba text. In particular Atari Ajanaku's Agbalagba and Agba Langba poems provide the data for this discursive analysis. Agbalagba presents the value of the aged, and the awe and appreciation which attends old age and/or the elderly among the Yoruba of South-Western Nigeria. Agba Langba which is examined in the next section presents the social bewilderment and stigmatizing disdain that accompanies an aged's social misnomer in character'. Agbalagba is on pages 57 to 58 of Atari Ajanaku's Orin Ewuro. In conformity with the Yoruba social perception of the aged, Atari Ajanaku presents the aged as a saviour. The aged comforts, consoles and directs in the moments of bewilderment, sorrow and discomfit. The aged is socially expected to be benevolent, patient and a protector. Due to his experience and likely internalization of societal normative values, the aged is seen as an epitome of wisdom and a proponent of impeccable character. Hence the Agbalagba poems says:

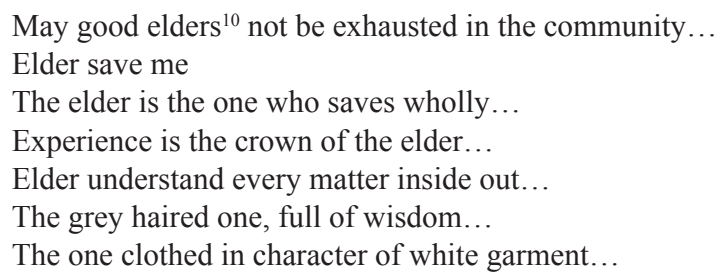

Atari Ajanaku describes experience as the crown of the aged. He also describes the aged as one with grey hair and full of wisdom. The "crown" represents the honour that the aged socially earns through experience among the Yoruba. This is further adumbrated in that even the grey hair is not viewed as an indication weakness and gradual descent into death, but as an indication of inward fullness of wisdom and the epitome of honour. At each instance of describing the depth of the experience and wisdom of the aged, Atari Ajanaku calls upon the elder to save. Of course, for the Yoruba, the aged saves not by physical strength,

9. The Atari Ajanaku graciously provided the English versions of the Agbalagba and Agba Langba poems. Hence, some verbatim English quotes are made where necessary. The English version represents Atari Ajanaku's initial presentation in Yoruba.

10. The "elder" as used here in meaning and social reference among the Yoruba, refers to the "aged", the gerontology concept commonly used in literature. 
but by wisdom that has been built by experience over the years. The depth and richness of the aged's experience and wisdom is expressed in the indigenous social thought which alludes to the vastness of the aged's experience. The Yoruba believe that even though the achievement of a younger person may compare with that of an older person, the younger's experience cannot be as vast as that of the older. The assumption that the aged is an epitome of experience also socially presents him with the value of commanding respect accentuating socially constructed efficacy in thoughts, discretion and action. The indigenous social thought describes the aged's discernment and direction for societal good as an indication of the aged's extraordinary capability. Hence, is assumed to have the capability, charisma and discretion to lead, decide, direct and guide without objection from the younger followership. The Yoruba social structure highly values and trusts the aged's judgment as almost infallible. The aged are reposed with the responsibility of calling individuals and the society at large to order when socially impairing decisions or actions are to be undertaken or have been undertaken. As harbingers of justice and fairplay, the aged as community elders must ensure things are done rightly.

An aged who would command such respect would be one who acts in accordance with epitomized normative values as constructed in Yoruba normative culture. Atari Ajanaku accentuates this by describing the aged as one clothed in character of white garment and the one who wears truthfulness as garment. The description of the aged as one clothed in character of white garment and truthfulness is indicative of the Yoruba normative value on character. The whole essence of socialization among the Yoruba is to produce the normative value of a good person. The good person must be truthful and impeccable in character. The socially constructed value of good personhood must be internalized and habitually expressed in social relations. An aged who adds value of good personhood to his disposition earns the respect of all. It is such an aged who would be consulted and, if socially possible, entrusted with the social capability of providing advice and discernment because of the supposed sincerity in the aged's relations with others and the experience he/she must have garnered over the years in his/her life journeys. With the social expectation of the aged's internalized sincerity in social interactions and the value of advancing the society, the indigenous social structure demands the younger generation's subjection to and respect for the aged who are assumed to be society's saviours. This explains the reason why Atari Ajanaku continually calls on the elder to "save" in the Agbalagba poem. Indeed, the aged saves through the disposition of his/her character as demanded by the local normative structure and not by physical 
strength. It is important to state, nevertheless, that an aged who presents dishonourable character is disdained (see also Owomoyela 2005, 51). Such an elder lacking decorum and discretion as dictated by the local and/or indigenous normative values indicating the socially expected character is described as the ignoble elder.

\section{The Ignoble Aged: $A$ gba Langba}

As much as the Yoruba socially places the aged within the construct of honour and prestige provided he/she conforms to socially approve normative standards, the Yoruba social structure also disdains the ignoble aged. The ignoble aged is the one who fails to act within socially approved norms. Such aged people are described as lacking sense of maturity, self-respect and dignity. The Yoruba social structure is embedded with normative values that abhors ignobility among the aged in all ramifications. Atari Ajanaku's Agba Langba poem (53-55) presents thoughts that are reflective of the social conception of the ignoble aged in Yoruba social structure. He states:

The elder is a dunghill...

The elder is tolerant

All those are the words of yesteryears...

In contemporary times

The elder does not save any longer...

Only irresponsible elders remain...

The stomach is the concern of the irresponsible elder

No longer the inner wisdom...

Neither what is right

Nor truthfulness...

The dupe's loot is their merchandise...

Atari Ajanaku's Agba Langba presents the despicable reality of the character of the ignoble aged who is beclouded by material lusts and expresses character unbecoming of the responsible aged person as defined by the Yoruba social structure. The poem starts by describing the aged as a "dunghill". The aged is described as a dunghill because he is expected to be modest, tolerant, persevering, listening and welcoming, irrespective of the potentially insulting disposition of the younger. The aged's strength and respect lies in his tolerance and perseverance and ability to afterwards calm fraying nerves with soothing words of wisdom that are based on experience. Irrespective of the behaviour of the younger person, the aged individual is expected to be tolerant and accommodating even though he must also admonish the wrong and commend the right. 
In the Agba Langba poem, Atari Ajanaku states that this value has become a thing of the past. The ignoble elder is not tolerant and corrective. The ignoble aged does not save nor mentor the younger ones to the right standards. Rather, the ignoble elder is corrupted with ill-gotten wealth. He briefly digresses to Babatunde Olatunji's (1978) fictional play titled Egbirin Ote (Package of Conspiracy) to present Oyeniran; a character in the book, as an example of an Agba Langba. Egbirin Ote depicts the corrupt and inept leadership bedeviling the society (Olabode and Ogundeji 1984). As the leader of his community, Oyeniran failed to exhibit the qualities of a good leader. He therefore lost the respect of his community.

The Agba Langba poem further states that the ignoble elder lacks critical reasoning. They rather follow the unprofitable popular trend, instead of thinking out genuine solution to social problems. The ignoble aged aimlessly follows the belittling trends and character of the younger generation and becomes demeaned and undignified. He is demeaned and undignified for lack of the "inner wisdom". The ignoble aged is also an untrustworthy, insincere and an epitome of deafening corruption; all in the quest for material gains. He does not seek the advancement of his sub-ordinates and/or younger ones. He rather works for their debasement. The young are to keep off the ignoble aged because he is not worthy of emulation. The character of the ignoble aged in its totality contradicts the societal normative standards. Hence, the ignoble aged is unworthy of being a role model. The ignoble aged bewilders the society and leaves the community appalled.

Finally, Atari Ajanaku reflects on the social reality that the younger will outlive the older in line with biological and social processes of societal reproduction. As the older ages, the younger gradually grows into old age. The younger assumes the position of the older, as generations turn, and once again, the new aged would be judged by the social value of his/her character as dictated by the local social structure. The Yoruba perceive the process of aging as such that demands a duty from the aging and the aged to lead the younger aright and seek their (the young's) advancement, as they (the aging and the aged) exhibit normative character. Otherwise, the memory of ignoble aged will wane into the ignoble past, devoid of social honour and glory that accompanies the memory of the departed aged. This is because the actions of the ignoble aged contradict the socially approved character (iwa), behavioral pattern (ihuwasi) and action (isesi) which would engender apposite sociation capable of ensuring unison (ajumose) for societal good. 


\section{Further Discussion: Character and the Yoruba Aged in Everyday LIFE}

As adumbrated above, character is a major fulcrum of everyday life among the Yoruba. The character an interacting individual reflects in his/ her actions, to a large extent, informs the reaction of the immediate social environment. An individual's character is also socially viewed as a measure of his/her social life, environment, background, pedigree and history. The action that reflects a person's character vis-a-vis the normative values, will also impact the reactions that would be engendered from the immediate social environment. Irrespective of age, the character of the individual will inform the reaction of the immediate interacting environment. Thus, the attachment of honour and prestige to the aging and the aged is not socially automatic. It is socially constructed and judged on the basis of the aged's character at present and over time.

Atari Ajanaku's allusion about the ignoble character of the contemporary elder is an indication of the social bewilderment that accompanies the social character of some elders who are entrapped by the ills of the modern society, and exhibit character that falls short of the standard set by the indigenous social structure. The contemporary aged is potentially exposed to the negativities of the ill-developed capitalistmaterialistic modern society, which demands the survival of the fittest and cares little about the welfare of the disadvantaged. The demands of the modern urban social and economic life have resulted in the breaking down of the kinship system and indigenous family that ensured that the aged are taken care of by blood relations (Olutayo and Omobowale 2006, Omobowale et al. 2010). Even in instances when the children are willing to take care of the welfare of their aged parents as demanded by the local social structure, they may be incapacitated by the debilitating economic situation in Nigeria. Potentially exposed without any assurance of adequate welfare in the days of aging induced frailty, the aging is constrained to compete with the younger and also employ anti-normative means to possibly provide for the days of potential lack. Thus, the younger is transformed from those to be cared, advised, guided and rolemodeled to a generation to be competed and discomfited by the older in contest for survival in everyday life, until the aged lacks the physical strength to compete.

Hence Atari Ajanaku describes the contemporary ignoble elder as intolerant and untruthful, who revels in ill-gotten wealth and dupes. He further maintains that such elders are found in the family, town, work place, business and even in religion. The poet simply captures the social degradation that has encapsulated the contemporary socio-political, eco- 
nomic and religious environments. Traditionally leadership positions, such as patrons, are entrusted to those who are advanced in age because the indigenous social structure opines that such aged people would advise and direct appropriately (Omobowale 2008). However, in contemporary times, age is not a determinant of noble character. The aged who desires the contemporary lifestyle of the younger generation and is constrained by the prevalent socio-economic environment that lacks social welfare for the aged, is constrained to neglect the socially constructed "noble character" as defined by the social structure to adopt the "witty and crafty" character of a shrewd materialist in the quest for survival. Hence, the social reality of the modern materialist environment, lacking adequate accommodation for the aged frail, builds a popular culture of corrupt enrichment and materialism as an individual gradually ages. This is with the assumption that whatever is accumulated in pre-frailty years would secure the aged's health and welfare when productive capability fails. Even though noble character in everyday life may be disregarded, the ignoble elder may potentially attract patronage even from the younger generation by building a clientelistic system which the layman sees as evidence of philanthropy, and thus, noble (see Omobowale and Olutayo 2007 for a case of patronage in Ibadan, Nigeria) ${ }^{11}$. In short, a so called ignoble elder lacking normative character may "purchase" loyalty and respect from the larger society through patronage. In modern times therefore, character is not the only denominator of social attribution of respect for the aged, a supposedly ignoble aged who has acquired ill-gotten wealth may attract respect and honour still among dependent clients, whose loyalty would be very valuable to the political system (Omobowale and Olutayo 2007, Omobowale 2008).

\section{Conclusion}

This paper has ethnographically analyzed the text of Atari Ajanaku's $A g$ balagba and Agba Langba poems on the aged's character. The research was guided by Akiwowo's Theory of Sociation in order to contextually examine the normative value of the aged's character among the Yoruba of South-Western Nigeria. The Yoruba social structure holds the elder in a state of high esteem as embodiment of experience, wisdom and bless-

11. In his lifetime, even at 80 years of age, Chief Lamidi Adedibu epitomized political thugery and violence as veritable instruments of political control in Ibadan, Nigeria. Ordinarily, he fell short of indigenously defined character normative value. Nevertheless, he earned huge honour among downtrodden clients and patronage from the political class who relied on Adedibu's clientelistic structure for political relevance. 
ing, capable of directing the society on the right course. The aged does not earn this esteem just by the virtue of his/her age, but by the virtue of the normative value of socially responsible person/individual that the aged should and/or must have internalized right from his/her younger years. Thus, the cumulative essence of the good person's character that an elder must have expressed over time and is evident and ascertained in his/her behavioral pattern and action adds up to confer honour and respect on the aged as an individual who works in unison with the community for common good. Otherwise, the aged person loses respect from all and sundry and he/she is disdained as a social misfit who should be ostracized. This thesis is clearly expressed in Atari Ajanaku's Agbalagba and Agba Langba poems. The noble aged (agbalagba) is the responsible elder who advances the interest of the younger and work for the societal good. The society celebrates noble aged and looks up to him/her for direction and advice on both knotty issues and everyday societal affairs. On the other hand, the ignoble aged (agba langba) is the irresponsible elder. Corrupt, selfish, ill-interested in societal good and deficient in good person's character, the ignoble aged assumes the position of social misfit that the society would osctracize; for the upcoming generation who would be socialized to become noble elders that would be desirous of working in unison for societal good; in character, pattern of behaviour and action.

\section{REFERENCES}

Adediran, Biodun. 1985. Research on pre-colonial western Yorubaland: A note on source-materials. Anthropos 80(4/6):545-554.

Adegbindin, Omotade. 2011. The problem of gerontocracy in Africa: The Yoruba perspective as illustrated in the ifa corpus. Human Affairs 21:454-469.

Adesina, Jimi O. 2002. Sociology and Yoruba studies: Epistemic intervention or doing sociology in the "vernacular." African Sociological Review 6(1):91-114.

Agbaje, James B. 2002. Proverbs: A strategy for resolving conflict in Yoruba society. Journal of African Cultural Studies 15(2):237-243.

Akanle, Olayinka and Akinpelu O. Olutayo. 2012. Ethnography of kinship constructions among international returnees in Nigeria: Proverbs as horse of words. Journal of Anthropological Research 68(2).

2011. Kinship construction variability among Nigerian international migrants: the context of contemporary diaspora. Human Affairs 21(4):470 480.

Akinyemi, Akintunde. 2003. Yoruba oral literature: A source of indigenous education for children. Journal of African Cultural Studies 16(2):161-179. 
Akiwowo, Akinsola. 1980. Ajobi and Ajogbe: Variations on the Theme of Sociation Inaugural Lecture Series 46. Ife: University of Ife Press.

1986a. Contributions to the sociology of knowledge from an oral poetry. International Sociology 1(4):343-358.

1986b. Asuwada-Eniyan Ife: Annals of the Institute of Cultural Studies 1:113-123.

Alana, O.E. 2004. Traditional religion. In Mike S. Lawal, Matthew N.O. Sadiku, and P. Ade Dopamu, eds., Understanding Yoruba Life \& Culture. New Jersey: Africa World Press, Inc.

Amstadter, Ananda B., Kristyn Zajac, Martha Strachan, Melba A. Hernandez, Dean G. Kilpatrick, and Ron Acierno. 2011. Prevalence and correlates of elder mistreatment in South Carolina: The South Carolina elder mistreatment study. Journal of Interpersonal Violence 26(15):2947-2972.

Atari Ajanaku. 1998. Orin Ewuro. Ibadan: Ibadan Cultural Studies Group, University of Ibadan.

Baldridge, David. 2001. Indian elders: Family traditions in crisis. American Behavioral Scientist 44(9):1515-1527.

Bamgbose, Ayo. 1970. Word play in Yoruba poetry. International Journal of American Linguistics 36(2):110-116.

Begle, Angela M., Martha Strachan, Joshua M. Cisler, Ananda B. Amstadter, Melba Hernandez, and Ron Acierno. 2011. Elder mistreatment and emotional symptoms among older adults in a largely rural population: The South Carolina elder mistreatment study. Journal of Interpersonal Violence 26(11):2321-2332.

Blaikie, Andrew. 1999. Aging and Popular Culture. New York: Cambridge University Press.

Boland, Eavan. 1994. Making the difference: Erotism and aging in the work of the woman poet. The American Poetry Review 23(2):27-32.

Brozowski, Karl and David R. Hall. 2010. Aging and risk: Physical and sexual abuse of elders in Canada. Journal of Interpersonal Violence 25(7):11831199

Bužgová, Radka. 2009. Elder abuse and mistreatment in residential settings. Nursing Ethics 16(1):110-126.

Christoffersen, Tor. 1974. Gerontology: Towards a general theory and a research strategy. Acta Sociologica 17(4):393-407.

Clark, Martha. 1980. The poetry of aging: Views of old age in contemporary poetry. The Gerontologist 20(2):188-191.

Conrad, Rachel. 2012. 'My future doesn't know ME': Time and subjectivity in poetry by young people. Childhood 19(2):204-218.

Coupland, Justine. 2007. Gendered discourse on the 'problem' of aging: Consumerized solutions. Discourse \& Communications 1(1):37-61. 
Cummings, Dave. 2002 .'Now with my hand I cover Afric': A love-poem sent by Stephen Spender to William Plomer. Journal of European Studies 32:223-233.

Daniel, Jack L.,Geneva Smitherman-Donaldson, and Milford A. Jeremiah. 1987. Makin' a way outa no way: The proverb tradition in the black experience. Journal of Black Studies 17(4):482-508.

Faleti, Adebayo. 2009. Omoluabi: The golden attribute of a Yorubaman. Pp. 113-128 in Adedotun Ogundeji and Adeniyi Akangbe, eds., Omoluabi: Its Concept and Education in Yoruba Land. Ibadan: Ibadan Cultural Studies Group, University of Ibadan.

Ganetz, Hillevi. 1994. The female body, the soul and modernity: A dichotomy reflected in a poem and a rock text. Young 2(3):49-62.

Hagley, Carol R. 1988. Aging in the fiction of Jean Rhys. World Literature Written in English 28(1):115-125.

Hepworth, Mike. 2000. Stories of Aging. Burkingham: Open University Press. 2003 Fiction and social gerontology: The novelist Stanley Middleton on aging. Generations 27(3):84-88.

Hodell, Emily C., Jonathan M. Golding, John A. Yozwiak, Gregory S. Bradshaw, Terri L. Kinstle, and Dorothy F. Marsil. 2009. The perception of elder sexual abuse in the courtroom. Violence Against Women 15(6):678-698.

Ihinger-Tallman, Marilyn. 1987. The American family. Journal of Family Issues 8:444-447.

Jamieson, Sara. 2004. The fiction of agelessness: Work, leisure, and aging in Alice Munro's "Pictures of the Ice." Studies in Canadian Literature/ Études en Literature Canadienne 29:106-128.

Johnson, Nan E. and Jacob J. Climo. 2000. Aging and eldercare in lesser developed countries. Journal of Family Issues 21(6):683-691.

Krekula, Clary. 2007. The intersection of age and gender: Reworking gender theory and social gerontology. Current Sociology 55(2):155-171.

Lawuyi, O.B. and Olufemi Taiwo. 1990. Towards an African sociological tradition: A rejoinder to Akiwowo and Makinde. International Sociology 5(1):57-73.

McCabe, Louise F. 2011. Alcohol, aging and dementia: A Scottish perspective. Dementia 10(2):149-163.

Makinde, Akin. 1988. Asuwada principle: An analysis of Akiwowo's contributions to the sociology of knowledge from an African perspective. International Sociology 3(1):61-76.

Marshall, Barbara L. 2006. The new virility: Viagra, male aging and sexual function. Sexualities 9(3):345-362.

Marshall, Barbara L. and Stephen Katz. 2002. Forever functional: Sexual fitness and the aging male body. Body \& Society 8(4):43-70. 
Moran, Joe. Aging and identity in dementia narratives. Cultural Values 5(2):245260.

Nyamnjoh, Francis B. 2012. 'Potted plants in greenhouse': A reflection on the resilience of colonial education in Africa. Journal of Asian and African Studies 4 (2):129-154.

Ogundeji, Adedotun P. 1991. Introduction to Yoruba Oral Literature (Ifaara si Litireso Alohun Yoruba). Ibadan: The Department of Adult Education, University of Ibadan, Nigeria.

- Ede Yoruba gege bi oko ti a fi $n$ tu iwa omoluabi gunle sebunte ayo lawujo. Pp. 69-88 in Adedotun Ogundeji and Adeniyi Akangbe, eds., Omoluabi: Its Concept and Education in Yoruba Land Ibadan: Ibadan Cultural Studies Group, University of Ibadan.

Ojoade, J.O. 1983. African sexual proverbs: Some Yoruba examples. Folklore 94(II):201-213.

Olabode, Afolabi and Adedotun Ogundeji. 1984. Iwe Afinimona Lori Atoto Arere ati Egbirin Ote. Unpublished monograph.

Olajubu, Oludare. 1972. References to sex in Yoruba oral literature. Journal of American Folklore 85(336):152-166.

Olatunji, Babatunde. 1978. Egbirin Ote. Ibadan, Nigeria: Oxford University Press.

Olatunji, Olatunde O. 1970. Characteristic Features of Yoruba Oral Poetry. (Ph.D. Thesis). Ibadan, Nigeria: University of Ibadan.

1979. The Yoruba oral poet and society. Research in African Literatures 10(2):179-207.

1984. Features of Yoruba Oral Poetry. Ibadan: Ibadan University Press.

Olutayo, Akinpelu O. 2012. 'Verstehen,' everyday sociology and development: Incorporating African indigenous knowledge. Critical Sociology 0896920512446094, first published online on 17 September 2012. doi:10.1177/0896920512446094

Olutayo Akinpelu Olutayo and Ayokunle Olumuyiwa Omobowale. 2006. The youth and the family in transition in Nigeria. Review of Sociology of the Hungarian Sociological Association 12:1-11.

Omobowale, Ayokunle O. 2008a. Clientelism and social structure: An analysis of patronage in Yoruba social thought. Afrika Spectrum 43(2):203-224. $2008 \mathrm{~b}$. The political instrumentalization of violence in Nigeria's fourth republic. Nigerian Journal of Sociology and Anthropology 6:85-103.

Omobowale Ayokunle Olumuyiwa and Akinpelu Olanrewaju Olutayo. 2007. Chief Lamidi Adedibu and patronage politics in Nigeria. Journal of Modern African Studies 45(3):425-446. 
Omobowale, Ayokunle Oluyiwa, Mofeyisara Oluwatoyin Omobowale, and Olawale Ajani. 2010. Emigration and the social value of remittances in Nigeria. Pp. 127-136 in E. Yewah and Dimeji Togunde, eds., Across the Atlantic: Immigrants in the United States. Illinois: Common Ground Publishers.

Owomoyela, Oyekan. 1972. The sociology of sex and crudity in Yoruba proverbs. Proverbium 20:751-758.

2005. Yoruba Proverbs. Lincoln, NE and London: University of Nebraska Press.

Payne, M.W. 1992. Akiwowo, orature and divination: Approaches to the construction of an emic sociological paradigm of society. Sociological Analysis 53(2):175-187.

Post, Lori, Connie Page,Thomas Conner, Artem Prokhorov, Yu Fang, and Brian J. Biroscak. 2010. Elder abuse in long-term care: Types, patterns, and risk factors. Research on Aging 32(3):323-348.

Ranzijn, Rob. 2010. Active aging-another way to oppress marginalized and disadvantaged elders? Journal of Health Psychology 15(5):716-723.

Richards, David. 1984. Owe l'esin òrò: Proverbs like horses: Wole Soyinka's Death and the King's Horseman. The Journal of Commonwealth Literature 19(1):86-97.

Richardson, Margaret and Theodore E. Zorn. 2012. Interactions at the elder-organization interface: Elders' experiences. Research on Aging 20(10):120 .

Salawu, Abiodun. 2011. The paradigm of ethical development for civilized leadership in Africa. Leadership 8(1):17-27.

Sanda, Muyiwa. 1988. In defence of indigenisation in sociological theories. International Sociology 3(2):189-199.

Shijun, Su. 1993. Models for bringing up children. A literary approach to the differences between Chinese and western thinking: An essay. Childhood $1: 202-211$.

Sigurdardottir, Sigurveig H., Gerdt Sundstrom, B.O. Malmberg, and Marie Ernsth Bravell. 2012. Needs and care of older people living at home in Iceland. Scandinavian Journal of Public Health 40(1):1-9.

Smyer, Tish and Michele C. Clark. 2011. A cultural paradox: Elder abuse in the native American community. Home Health Care Management and Practice 23(3):201-206.

Sztompka, Piotr. 2011. Another sociological utopia. Contemporary Sociology 40(4):388-396.

Zhan, Heying J. and Rhonda J.V. Montgomery. 2003. Gender and elder care in China: The influence of filial piety and structural constraints. Gender and Society 17(2):209-229. 
Ayokunle Olumuyiwa Omobowale (Lecturer, University of Ibadan, Nigeria) holds a PhD in Sociology from the University of Ibadan where he also teaches. His research interests include Development, Culture, Rural Studies, Politics and Urbanization. He is a recipient of University of Ibadan Postgraduate School Award for scholarly publication; 2007, IFRA Research Fellowship; 2009 and ACLS-AHP Post-Doctoral Fellowship; 2010. He is the author of The Tokunbo Phenomenon and the Second-hand Economy in Nigeria (Oxford: Peter Lang Publishing, 2013).

muyiwaking@yahoo.com. 